\title{
PKM Perawatan dan Perbaikan Alat-Alat Rumah Tangga Listrik Untuk Mengatasi Dampak Covid-19 di Kab. Gowa
}

\author{
Muliadi ${ }^{1}$, Alifya $\mathrm{NFH}^{2}$ \\ ${ }^{1,2}$ Jurusan Pendidikan Teknik Elektro Fakultas Teknik Universitas Negeri Makassar
}

\begin{abstract}
This community service activity aims to provide training on maintenance and repair of electrical and electronic equipment for households to the Child Social Welfare Institution (LKSA) in Kalegowa Subdistrict, Somba Opu District, Gowa Regency which is a partner of the activity. The methods used in this service were: lectures, questions and answers, discussions and demonstration methods were used for training. The solution taken in solving partner problems, namely training activities for maintenance and repair of household electrical appliances based on project work is carried out to provide knowledge about basic concepts of electricity and electronics, basic electronic components, and repair of electrical household appliances. The results achieved in this service activity are 10 foster children of productive age from partners who are skilled and competent in repairing electrical household appliances, have knowledge of how to use electric and electronic measuring instruments, how to use electrical and electronic equipment, workshop management, $\mathrm{K} 3$, and entrepreneurship.
\end{abstract}

Keywords: Foster Children, Maintenance, Repair, Electrical Equipment

\section{PENDAHULUAN}

Lembaga Kesejahteraan Sosial Anak (LKSA) adalah organisasi sosial atau perkumpulan sosial yang melaksanakan Program Kesejahteraan Sosial Anak (PKSA) yang dibentuk oleh masyarakat atau difasilitasi pemerintah, baik yang berbadan hukum maupun yang tidak berbadan hukum. LKSA sebagai mitra pemerintah didalam pelaksanaan perlindungan dan pengasuhan yang baik, diharapkan dapat memberikan kontribusi dalam memajukan dan melindungi hak-hak anak.

Menurut standar nasional pengasuhan untuk lembaga kesejahteraan sosial anak (LKSA) yang ditetapkan dalam peraturan Kementrian Sosial Republik Indonesia Nomor : 30/HUK/2011 tentang Standar Nasional Pengasuhan Anak untuk Lembaga Kesejahteraan Sosial Anak, salah satu hal yang harus diterapkan dalam pendekatan kepada anak adalah pengakuan bahwa Lembaga Kesejahteraan Sosial Anak yang sebelumnya dikenal dengan istilah LKSA memiliki potensi untuk mendukung terbangunnya sistem pengasuhan anak yang mendukung pengasuhan berbasis keluarga sesuai dengan kepentingan terbaik anak.

LKSA dirancang sebagai upaya yang terarah, terpadu dan berkelanjutan yang dilakukan pemerintah, pemerintah daerah dan masyarakat dalam bentuk pelayanan sosial dan bantuan kesejahteraan sosial anak bersyarat (conditional cash transfer) yang meliputi :

a. Bantuan sosial/subsidi pemenuhan hak dasar (akte kelahiran, tempat tinggal, nutrisi, air bersih, dll.)

b. Peningkatan aksesibilitas terhadap pelayanan sosial dasar (akses pendidikan dasar, akses pelayanan kesehatan, askes pelayanan rehabilitasi sosial, dll.)

c. Pengembangan potensi diri dan kreatifitas anak.

d. Penguatan tanggung jawab orang tua/keluarga dalam pengasuhan dan perlindungan anak.

e. Penguatan kelembagaan kesejahteraan sosial anak.

Pengorganisasian kegiatan LKSA dirancang sedemikian rupa agar bantuan sosial bagi anak dan keluarga, serta bantuan operasional bagi lembaga mitra kerja (Lembaga Kesejahteraan Sosial Anak) dapat disalurkan secara tepat sasaran, transparan 
dan dapat dipertanggungjawabkan sesuai dengan ketentuan peraturan perundang-undangan yang berlaku. yang terarah, terpadu, dan berkelanjutan yang dilakukan pemerintah, pemerintah daerah, dan masyarakat dalam bentuk pelayanan sosial guna memenuhi kebutuhan dasar anak, yang meliputi bantuan pemenuhan kebutuhan dasar, aksesibilitas pelayanan sosial dasar, peningkatan potensi diri dan kreativitas anak, penguatan orang tua/keluarga dan penguatan lembaga kesejahteraan sosial anak.

Berdasarkan Instruksi Presiden Nomor 3 Tahun 2010 tentang Program Pembangunan yang Berkeadilan, Program Kesejahteraan Sosial Anak (PKSA) merupakan upaya sistemik dan berkelanjutan yang dikembangkan Kementerian Sosial Republik Indonesia dalam merespon perkembangan permasalahan kesejahteraan sosial anak di seluruh wilayah Indonesia. Program ini dirancang untuk menghasilkan upaya yang terarah, terpadu dan berkelanjutan yang dilakukan pemerintah, pemerintah daerah dan masyarakat dalam bentuk pelayanan sosial dan bantuan kesejahteraan sosial anak, yang menjangkau seluruh anak yang mengalami masalah sosial sehingga mereka dapat menikmati kehidupan dan berada dalam lingkungan pengasuhan yang memungkinkannya untuk tumbuh dan berkembang secara optimal sesuai potensinya.

Sasaran penerima layanan PKSA: anak, orang tua/ keluarga maupun lembaga kesejahteraan sosial yang menjadi mitra pendamping, harus memenuhi persyaratan (conditionalities) sebagai berikut:

a. Adanya perubahan sikap dan perilaku sosial anak ke arah positif

b. Intensitas kehadiran anak dalam layanan sosial dasar dari berbagai organisasi/ lembaga semakin meningkat.

c. Intensitas kehadiran anak dalam kegiatan pengembangan potensi diri/ kreativitas anak semakin meningkat.

d. Tanggung jawab orang tua/ keluarga dalam pengasuhan dan perlindungan anak semakin meningkat. e. Peran Lembaga Kesejahteraan Sosial Anak yang bermitra dengan Kementerian Sosial semakin efektif dalam mendampingi anak sehingga anak dapat terhindar dari penelantaran, eksploitasi, kekerasan dan diskriminasi.

Menurut Panduan PKSA tahun 2014, bantuan dari PKSA akan berakhir apabila salah satu dari kriteria berikut telah dipenuhi: (1) Penerima manfaat sudah berusia di atas 18 tahun, (2) pindah ke tempat lain, (3) keberadaan mereka tetap tidak diketahui untuk jangka waktu 3 bulan, (4) meninggal dunia, (5) menerima lebih dari satu program yang sama dalam satu waktu, (6) orangtua dianggap mampu untuk memenuhi hak-hak anak, (7) penerima manfaat menikah, (8) orangtua tidak mengikuti pertemuan FDS sampai tiga kali dalam satu tahun, (9) partisipasi anak dalam mengakses layanan (pengasuhan, kesehatan, pendidikan, dan pengembangan diri) di bawah $75 \%$, dan (10) penerima manfaat mengikuti STILA (Strategi Tindak Lanjut) dari PKSA.

Lembaga Kesejahteraan Sosial Anak (LKSA) di Kabupaten Gowa diwujudkan dalam bentuk LKSA yang merupakan salah satu lembaga perlindungan anak yang berfungsi untuk memberikan perlindungan terhadap hak-hak anak (UndangUndang RI Nomor 23 Tahun 2002, perlindungan anak). Penanganan masalah kesejahteraan sosial anak terlantar di Kabupaten Gowa, melalui sistem panti adalah dimana asuhan diberikan kepada anakanak yang sangat terlantar atau karena tingkah lakunya yang tidak bisa diterima oleh keluarga asuhnya. Asuhan dalam panti adalah sebagai pengganti orangtua bagi anak yang terlantar sehingga anak merasa terjamin hidup dalam kelompok anak-anak. Pelayanan yang diberikan berupa penyediaan fasilitas-fasilitas, pemenuhan kebutuhan sandang, pangan, pendidikan, bimbingan rohani serta keterampilan sehingga diharapkan anak- anak tersebut dapat mengembangkan pribadi, potensi, kemampuan dan minatnya secara optimal. Sedangkan asuhan nonpanti adalah asuhan secara berkelompok dalam rumah bagi anak-anak remaja yang tidak dapat menyesuaikan diri dengan keluarga asuhnya. 
Jumlah anak yang ada pada seluruh LKSA Kabupaten Gowa pada tahun 2014 tercatat sebesar 1.615 dengan perbandingan 785 laki-laki dan 830 perempuan, sedangkan pada tahun 2015 mengalami penurunan sebesar 471 orang anak dengan perbandingan jumlah laki-laki 179 dan 292 perempuan. (Gambar 1).

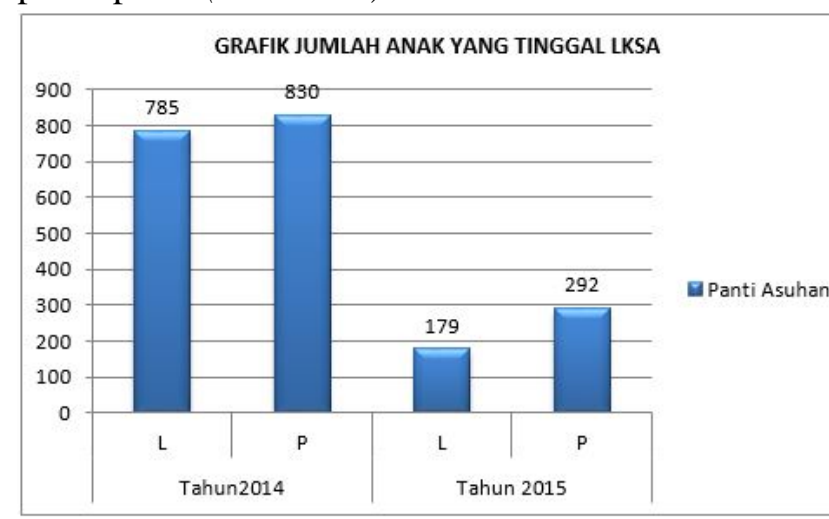

Gambar 1. Jumlah anak yang ada pada seluruh LKSA Kab. Gowa pada tahun 2014. (Dinas Sosial Kab. Gowa 2015).

LKSA Nur Uswatun Hasanah sebagai mitra kegiatan PKM terletak di Kelurahan Kalegowa Kecamatan Somba Opu Kabupaten Gowa. LKSA Nur Uswatun Hasanah didirikan pada tahun 2001 membina 25 anak asuh dengan jumlah pengelola sebanyak 5 orang. Jumlah usia produktif $(>15$ tahun) sebanyak 12 orang. Luas lahan sebesar 300 $\mathrm{m}^{2}$, dan luas bangunan sebesar $84 \mathrm{~m}^{2}$.

LKSA tersebut membina anak asuh yang termasuk dalam kategori anak terlantar, anak yatim dan piatu, serta anak dari keluarga tidak mampu (miskin). Selain pendidikan formal, anakanak panti juga memperoleh pendidikan non formal yakni pendidikan agama Islam, pendidikan akhlak dan etika serta membuang kebiasaan atau kepribadian yang buruk seperti mencuri, berbohong, berkata tidak sopan, tidak patuh kepada orang yang lebih tua dan masih banyak lagi yang lainnya.

Disisi lain, adanya batasan umur atau tingkat pendidikan formal yang ditanggung oleh pengelola LKSA menyebabkan timbulnya perasaan resah dan was-was bagi anak asuh yang berumur di atas 15 tahun atau yang menempuh pendidikan di jenjang menengah atas. Karena setelah menamatkan pendidikan di tingkat menengah atas, mereka dianggap sudah mampu mandiri sehingga pengelola panti tidak lagi menjamin biaya hidup apalagi biaya kuliah. Keinginan untuk melanjutkan pendidikan ke jenjang yang lebih tinggi atau kuliah terpaksa harus "dikubur" dalam-dalam akibat tidak adanya biaya. Pada dasarnya anak-anak panti ini mempunyai minat kerja yang tinggi, hal ini terkendala akibat minimnya keterampilan yang dimiliki ditambah dengan terbatasnya lapangan kerja yang tersedia mengakibatkan kesempatan untuk bekerja menjadi berkurang. Apalagi selama hidup di panti, mereka belum pernah dibekali keterampilan atau dididik untuk berwirausaha, hanya memperoleh pendidikan keagamaan.

Berdasarkan analisis situasi di atas, maka dirumuskan masalah secara spesifik sebagai berikut:

1. Pengelola LKSA tidak dapat memberikan keterampilan tambahan ataupun kecakapan hidup (life skills) yang memadai bagi anak asuhnya selain dibidang keagamaan.

2. Pengelola LKSA memberlakukan batasan umur atau jenjang pendidikan bagi anak asuhnya.

3. Kurangnya lembaga/institusi yang memberikan pembinaan/pelatihan kepada anak asuh penghuni LKSA.

Kegiatan ini bertujuan untuk :

1. Memberikan pelatihan perawatan dan perbaikan alat-alat rumah tangga listrik kepada anak asuh penghuni LKSA Nur Uswatun Hasanah di Kelurahan Kalegowa Kecamatan Somba Opu yang dijadikan mitra kegiatan.

2. Memberikan pelatihan tentang pengetahuan K3, manajemen bengkel dan kewirausahaan kepada mitra kegiatan

\section{METODE PELAKSANAAN}

Metode yang digunakan dalam kegiatan Program Kemitraan Masyarakat ini adalah: ceramah, tanya jawab, diskusi dan untuk pelatihan digunakan metode demonstrasi. Pelaksanaan kegiatan PKM ini telah memadukan pembelajaran konvensional dengan pembelajaran online melalui media sosial yaitu channel youtube dengan nama channel "MULIADI UNM". Semua materi yang 
disajikan secara konvensional telah dibuatkan panduan belajar mandiri berupa video tutorial yang dapat diputar ulang sesuai kebutuhan peserta pelatihan. Adapun metode yang digunakan dalam penyampaian materi pelatihan secara konvensional diuraikan sebagai berikut :

1. Metode ceramah dan tanya jawab digunakan untuk: (a) menjelaskan jenis-jenis dan fungsi alat-alat rumah tangga listrik seperti Setrika Listrik, Rice Cooker, Mixer, Blender, dan Kipas Angin. (b) menjelaskan jenis-jenis komponen yang digunakan pada alat-alat rumah tangga listrik seperti Setrika Listrik, Rice Cooker, Mixer, Blender, dan Kipas Angin. (c) menjelaskan cara mengukur dan menentukan rusak atau tidaknya komponen yang digunakan pada alat-alat rumah tangga listrik seperti Setrika Listrik, Rice Cooker, Mixer, Blender, dan Kipas Angin. (d) menjelaskan skema rangkaian kelistrikan dari alat-alat rumah tangga listrik seperti Setrika Listrik, Rice Cooker, Mixer, Blender, dan Kipas Angin.

2. Metode pemberian tugas digunakan untuk menemukan jenis-jenis komponen yang digunakan pada alat-alat rumah tangga listrik seperti Setrika Listrik, Rice Cooker, Mixer, Blender, dan Kipas Angin sesuai yang telah dijelaskan.

3. Metode simulasi dan demonstrasi digunakan untuk: (a) mendemonstrasikan cara mengukur komponen yang digunakan pada alat-alat rumah tangga listrik seperti Setrika Listrik, Rice Cooker, Mixer, Blender, dan Kipas Angin. (b) mendemonstrasikan Mendemonstrasikan cara menentukan rusak atau tidaknya komponen yang digunakan pada alat-alat rumah tangga listrik seperti Setrika Listrik, Rice Cooker, Mixer, Blender, dan Kipas Angin. Peserta pelatihan mengidentifikasi komponenkomponen yang diberikan dan menyimpulkan kondisi komponen tersebut, baik atau sudah rusak. (c) mendemonstrasikan klasifikasi kerusakan pada alat-alat rumah tangga listrik seperti Setrika Listrik, Rice Cooker, Mixer, Blender, dan Kipas Angin. Peserta pelatihan menentukan klasifikasi kerusakan pada alat-alat rumah tangga listrik seperti Setrika Listrik, Rice Cooker, Mixer, Blender, dan Kipas Angin yang diberikan.

4. Metode Praktik digunakan untuk melaksanakan Praktik memperbaiki kerusakan pada alat-alat rumah tangga listrik seperti Setrika Listrik, Rice Cooker, Mixer, Blender, dan Kipas Angin sesuai dengan gejala kerusakan yang diberikan.

5. Metode monitoring dan evaluasi, melakukan pemeriksaan terhadap hasil praktikum yang dilakukan oleh peserta, selanjutnya memberikan pembimbingan jika masih ada yang belum terampil dan kompeten. Pelaksanaan Evaluasi dimaksudkan untuk mengetahui sejauh mana tujuan yang ditetapkan sebelumnya telah tercapai. Evaluasi dilaksanakan sebanyak 3 tahap yaitu tahap awal, evaluasi tahap proses, dan evaluasi tahap akhir: (a) evaluasi Tahap awal dilakukan untuk mengetahui kondisi awal dan kemampuan dasar serta kebutuhan masingmasing peserta. (b) evaluasi tahap proses dilakukan pada saat pelatihan berlangsung untuk mengetahui sejauhmana pelaksanaan kegiatan dapat diikuti oleh peserta. (c) evaluasi tahap akhir pelaksanaan kegiatan untuk mengetahui sejauhmana efektifitas pelaksanaan kegiatan dan bagaimana tingkat keberhasilan pelatihan yang diperoleh, sejauhmana tingkat penguasaan keterampilan para peserta pelatihan dan termotivasi untuk mengembangkan keterampilan yang dimiliki dalam menciptakan lapangan kerja baru di sektor jasa perawatan dan perbaikan alat-alat rumah tangga listrik.

Langkah-langkah yang ditempuh dalam pelaksanaan PKM Perawatan dan Perbaikan AlatAlat Rumah Tangga Listrik di LKSA Nur Uswatun Hasanah Kelurahan Kalegowa Kecamatan Somba Opu Kabupaten Gowa ini sebagai berikut:

1. Pelaksanaan program dengan metode ceramah, diskusi, pemberian tugas, dan praktik.

2. Seminar evaluasi di lokasi guna memperbaiki program yang telah dilaksanakan dan penyiapan program berikutnya.

3. Penyusunan laporan

4. Seminar akhir 


\section{HASIL DAN PEMBAHASAN}

Kegiatan PKM ini dilaksanakan di Kelurahan Kalegowa Kecamatan Somba Opu Kabupaten Gowa Sulawesi Selatan dengan jarak kurang lebih $4 \mathrm{~km}$ dari Fakultas Teknik UNM. Melalui program kemitraan masyarakat ini akan memberikan konstribusi bagi anak asuh yang dibina pada LKSA Nur Uswatun Hasanah dalam meningkatkan keterampilan dan penguasaan teknologi khususnya dibidang jasa perawatan dan perbaikan alat-alat rumah tangga listrik. Dengan adanya pelatihan perawatan dan perbaikan alat-alat rumah tangga listrik bagi anak asuh penghuni LKSA ini telah menghasilkan teknisi baru yang kompeten dibidang jasa perawatan dan perbaikan alat-alat rumah tangga listrik, dan diharapkan menjadi suatu peluang usaha baru bagi anak-anak asuh penghuni LKSA dibidang perawatan dan perbaikan alat-alat rumah tangga listrik.

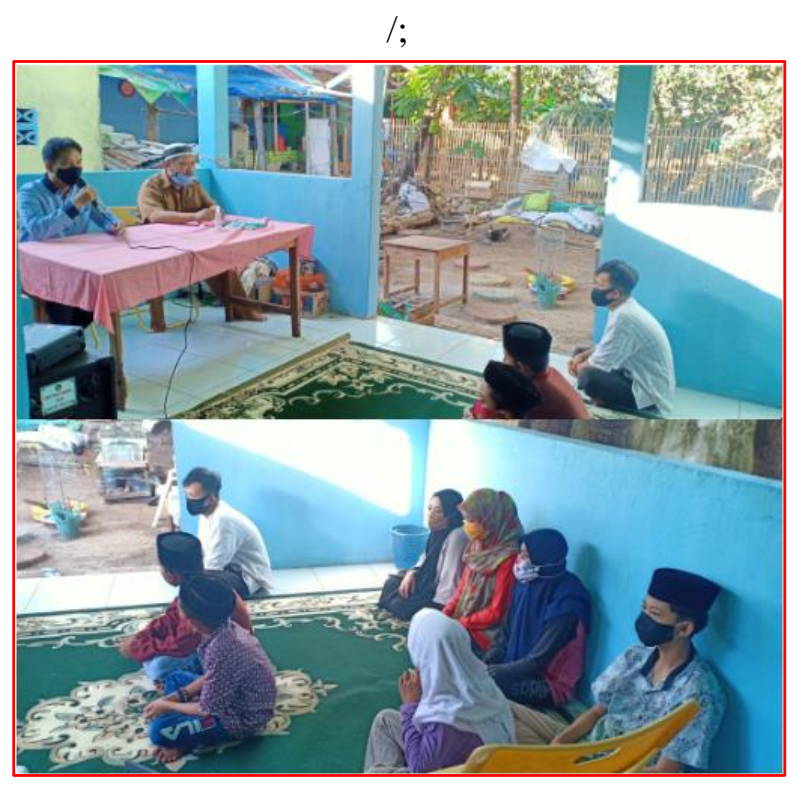

Gambar 2. Pembukaan Kegiatan PKM yang Dihadiri oleh Ketua LKSA Nur Uswatun Hasanah dan Peserta Pelatihan.

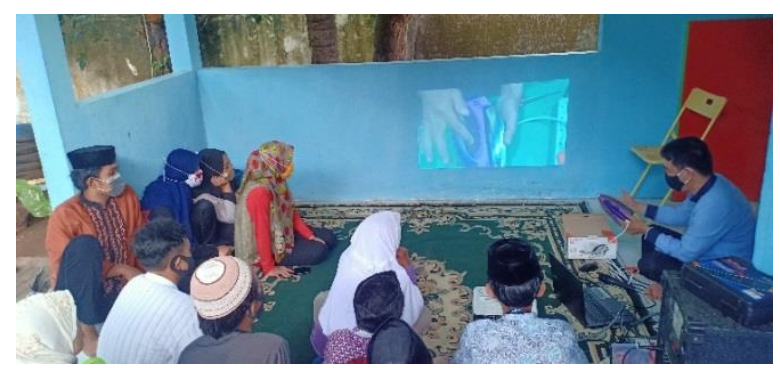

Gambar 3. Pelaksana PKM Memberikan Materi Praktik Memperbaiki Setrika Listrik dengan Memutarkan Video Tutorial yang ada di channel MULIADI UNM (Youtube)

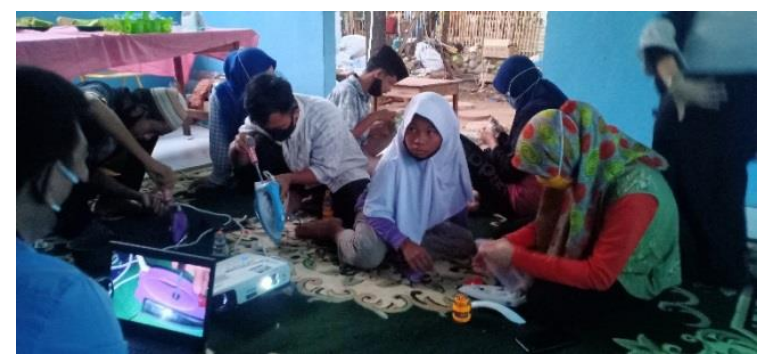

Gambar 4. Peserta Pelatihan Melakukan Praktik Memperbaiki Setrika Listrik dengan Mengikuti Panduan di Video Tutorial

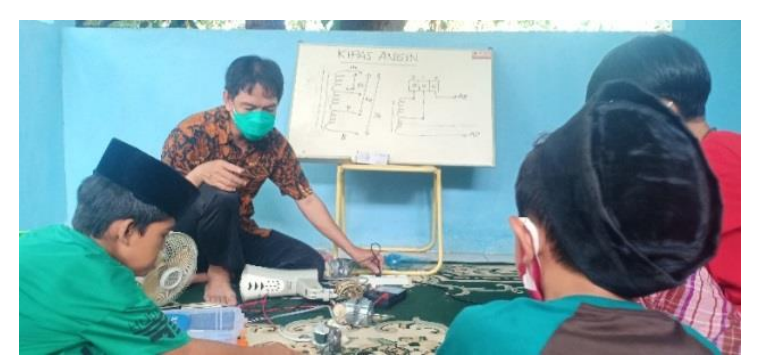

Gambar 5. Peserta Pelatihan Praktik Memperbaiki Kipas Angin

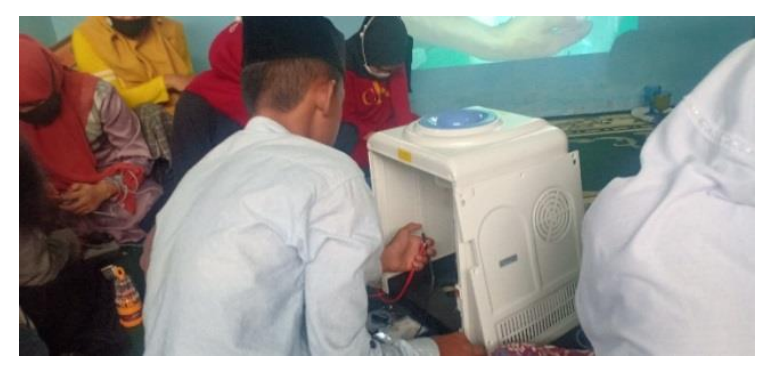

Gambar 6. Peserta Pelatihan Praktik Memperbaiki Dispenser

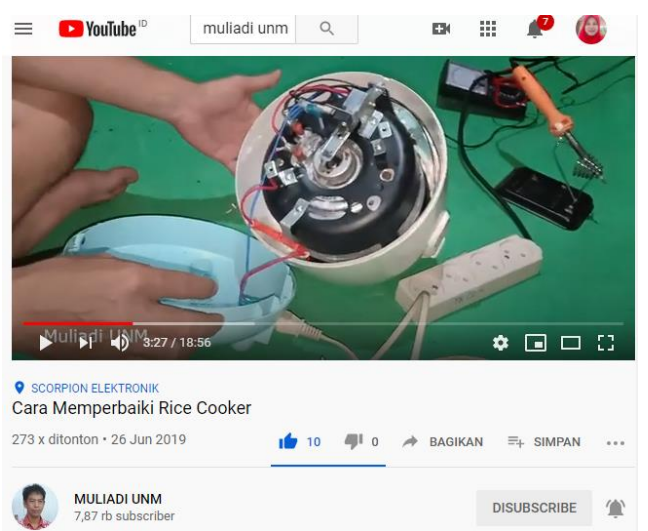

Gambar 7. Pembelajaran Online dengan menggunakan Channel Youtube

Hasil yang dicapai dari kegiatan ini adalah sebagai berikut: (1) partisipasi peserta pelatihan 
sangat tinggi, hal ini dilihat dari: (a) 100\% peserta mengikuti kegiatan pelatihan secara penuh waktu, (b) semua peserta aktif bertanya dan mengemukakan permasalahannya. (2) Daya serap materi pelatihan oleh peserta rata-rata baik terbukti pada saat diadakan pelatihan, $90 \%$ terampil dan kompeten dalam memperbaiki alat-alat rumah tangga listrik, walaupun masih ada peserta yang perlu diremedi (pembimbingan ulang). Namun berkat ketekunan dan keuletan peserta dalam mengikuti pelatihan, kekurangan tersebut dapat ditutupi walaupun harus dengan jalan diremedi. Disamping itu, peserta pelatihan dapat meningkatkan kompetensi keterampilannya secara mandiri dengan memanfaatkan video tutorial yang telah diunggah di channel youtube. Dapat diartikan bahwa pelaksanaan kegiatan Program Kemitraan Masyarakat ini berhasil dan sukses.

Penguasaan peralatan. berdasarkan hasil pengamatan selama pelaksanaan kegiatan menunjukkan bahwa peserta yang berjumlah 10 orang, terdapat 9 orang (90\%) dapat menggunakan peralatan dengan baik, dan 1 orang (10\%) kurang terampil menggunakan peralatan diakibatkan oleh faktor komunikasi dan latar belakang pendidikan yang masih rendah (belum tamat SMP) sehingga kesulitan dalam mempelajari alat ukur listrik. Tetapi pada penggunaan peralatan mekanik seperti obeng, tang, pinset, dan lain-lain tidak mengalami kesulitan. Kerjasama dan kekompakan peserta dalam mengikuti kegiatan sangat menunjang keberhasilan program. Hasil ini menunjukkan keberhasilan kegiatan berdasarkan indikator yang telah ditetapkan.

\section{Monitoring dan Evaluasi Program}

Monitoring dilaksanakan selama pelaksanaan kegiatan. Dilakukan minimal satu kali seminggu dengan memeriksa laporan berkala perawatan dan perbaikan alat-alat rumah tangga listrik yang dimiliki Lembaga Kesejahteraan Sosial Anak (LKSA) Nur Uswatun Hasanah Kelurahan Kalegowa. Kegiatan ini dilakukan untuk mengetahui sejauh mana pengetahuan dan keterampilan yang dimiliki anak asuh penghuni
LKSA dalam merawat dan memperbaiki alat-alat rumah tangga listrik.

Evaluasi tahap awal dilakukan untuk mengetahui kondisi awal dan kemampuan dasar serta kebutuhan masing-masing peserta. Hal ini dilakukan dengan menggunakan metode wawancara pada tiap peserta pelatihan mengenai: (a) pengetahuan komponen alat-alat rumah tangga listrik. (b) pengetahuan penggunaan alat ukur elektronika. (c) pengetahuan perawatan dan perbaikan alat-alat rumah tangga listrik.

Evaluasi tahap proses dilakukan pada saat pelatihan berlangsung untuk mengetahui sejauhmana pelaksanaan kegiatan dapat diikuti oleh peserta. Evaluasi dilakukan dengan cara observasi terhadap sikap serta perilaku para peserta pada saat mengikuti pelatihan perawatan dan perbaikan alat-alat rumah tangga listrik.

Evaluasi tahap akhir dilakukan di tahap akhir pelaksanaan kegiatan untuk mengetahui sejauh mana efektifitas pelaksanaan kegiatan dan bagaimana tingkat keberhasilan pelatihan yang diperoleh, serta sejauh mana tingkat penguasaan keterampilan para peserta pada pelatihan perawatan dan perbaikan alat-alat rumah tangga listrik.

Keberhasilan pelaksanaan pelatihan ini tentunya atas bantuan yang diberikan oleh Rektor UNM dan Ketua LP2M Universitas Negeri Makassar yang menyediakan dana, memberikan ijin dan mengarahkan kegiatan pelatihan sehingga berjalan sesuai yang direncanakan. Terciptanya kekompakan Tim Pelaksana, kedisiplinan dan keseriusan yang tinggi dari peserta pelatihan, dan dukungan dari aparat kelurahan, tokoh masyarakat dan pengurus Lembaga Kesejahteraan Sosial Anak (LKSA) Nur Uswatun Hasanah Kelurahan Kalegowa juga menjadi kunci keberhasilan sehingga kegiatan dapat terlaksana dengan baik.

Selain keberhasilan yang dikemukakan, kegiatan pelatihan ini juga mengalami kendala yang disebabkan antara lain latar belakang tingkat pendidikan peserta yang berbeda-beda dan bukan dari sekolah kejuruan sehingga peserta tidak memiliki dasar pengetahuan tentang perawatan dan perbaikan alat-alat rumah tangga listrik dan banyaknya kegiatan peserta pelatihan yang masih 
usia sekolah dan statusnya sebagai anak asuh penghuni LKSA dengan kegiatan rutin pengajian.

\section{KESIMPULAN}

1. Partisipasi peserta pelatihan sangat tinggi, hal ini dilihat dari: (a) $100 \%$ peserta mengikuti kegiatan pelatihan secara penuh waktu, (b) semua peserta aktif bertanya dan mengemukakan permasalahannya.

2. Daya serap materi pelatihan oleh peserta ratarata baik terbukti pada saat diadakan pelatihan, 90\% terampil dan kompeten dalam merawat dan memperbaiki alat-alat rumah tangga listrik.

3. Kerjasama dan kekompakan peserta dalam mengikuti kegiatan sangat menunjang keberhasilan program terutama dalam penguasaan penggunaan peralatan.

\section{DAFTAR PUSTAKA}

Badan Pusat Statistik Kab. Gowa. 2015. Hasil Sensus Penduduk 2015 Kabupaten Gowa. BPS. Bantaeng.

Dinas Sosial Prov. Sul-Sel. 2013. Panti Asuhan, Panti Jompo, dan Panti Rehabilitasi Provinsi Sulawesi Selatan Tahun 2008-2012. Makassar.

Surip. 2011. Implementasi model project work dalam pembelajaran mixing bahan kimia untuk meningkatkan karakter kerja profesional peserta didik. Yogyakarta. PTK (tidak dipublikasikan).

Informasi Laporan Penyelenggaraan

Pemerintahan Daerah (ILPPD) Kabupaten Gowa Tahun Anggaran 2013 (Online)

Undang-Undang Nomor 11 Tahun 2009 tentang Kesejahteraan Sosial. 